\title{
Impact of e-tendering on arrivals and prices of copra in Tiptur APMC
}

M.S. KISHORE, H.S. SRIKANTH AND BHEEMANGOUDA O. PATIL

Received : 28.04.2016; Revised : 14.08.2016; Accepted : 01.09.2016

\begin{abstract}
The study analyzes the impact of e-tendering initiative in Tiptur APMC on the various factors of copra market like arrivals, average prices, minimum and maximum prices, growth of arrivals and prices before and after the initiative, stability of the growth and seasonality of arrivals and prices of copra in Tiptur market. Secondary data relating to arrivals and prices of copra in Tiptur APMC during two periods viz., 2002 to 2010 (pre-intervention period) and 2011 to 2015 (post-intervention period) were used for the study. The annual total arrivals of copra in Tiptur market has increased from 1,43,496 quintals in 2002 to $4,10,877$ quintals in 2015 , with a compounded annual growth rate of 12.82 per cent which was significant at 1 per cent level. The modal prices of copra have increased at a rate of 9.59 per cent which was significant at 1 per cent level. In the period wise analysis, the total arrivals and average price of copra during pre-intervention period increased at a rate of 13.46 and 7.20 per cent which was not significant. The total arrivals and average prices of copra during post-intervention period increased at a rate of -19.1 and 25.81 per cent which were non-significant. There was a very weak negative relationship (correlation of -0.18) between the total annual arrivals and annual average prices in the pre-intervention period, whereas, there was found to be a strong negative relationship (correlation of -0.91) between total annual arrivals and annual average prices in the postintervention period. Further, it was observed that the minimum prices in different months during post-intervention period had increased considerably after the introduction of e-tendering. The monthly maximum prices of copra during the post-intervention period had also increased considerably. The variation in prices and arrivals had moderated in the post-intervention period. Overall it could be concluded that the e-tendering initiative has brought in some improvements in the arrivals and prices in terms of reduction in variations, increased minimum and maximum monthly prices. It has also brought more stability to the arrivals and prices of copra in Tiptur market.
\end{abstract}

KEY WORDS : Tiptur, Copra, E-tendering, Arrivals, Average prices, Compound annual growth rate

How to cite this paper : Kishore, M.S. Srikanth, H.S. and Patil, Bheemangouda O. (2016). Impact of e-tendering on arrivals and prices of copra in Tiptur APMC. Internat. J. Com. \& Bus. Manage, 9(2) : 119-127. DOI: 10.15740/HAS/IJCBM/9.2/119-127.

\section{MEMBERS OF THE RESEARCH FORUM}

Correspondence to:

M.S. KISHORE, Department of Agribusiness Management, College of Agriculture, University of Agricultural Sciences, DHARWAD (KARNATAKA) INDIA

Email: nabuta127@gmail.com

Authors' affiliations:

H.S. SRIKANTH, Department of Agribusiness Management, College of Agriculture, University of Agricultural Sciences, DHARWAD (KARNATAKA) INDIA

Email: srikanthuas@gmail.com $--\frac{-}{\text { внE }}-\frac{-}{\mathrm{P}}-----------$ Economics, College of Agriculture, University of Agricultural Sciences, DHARWAD (KARNATAKA) INDIA

Email: bheemagriecon@gmail.com 